\title{
ANALISIS BIAYA MAKAN TERHADAP KETERSEDIAAN MAKANAN SERTA TINGKAT KECUKUPAN GIZI SANTRI DI PONDOK PESANTREN DARUL ARQAM GARUT
}

\section{Cost Analysis towards the Availability of Food as well as the Nutritional Adequacy Level of Santri in Darul Arqam Boarding School Garut}

\author{
Ahmad Sahl Sudrajat, Tiurma Sinaga \\ Departemen Gizi Masyarakat, Fakultas Ekologi Manusia, Institut Pertanian Bogor,16680 \\ E-mail: ahmadsahl30@gmail.com
}

\section{ABSTRACT}

The general objective of this study was to analyze the cost control towards the food availability and the nutritional adequacy level of the female santri in Darul Arqam Boarding School, Garut. The study was held in April until June 2015 using the cross-sectional study. The sample was taken purposively with a total of 86 people. The result showed that the food service management was able to manage over 88.09 percent of total funds. The pearson correlation showed that there was no significant correlation $(p>0,05)$ between the cost with the energy, protein, fat, vitamin $\mathrm{C}$, and iron availabilities. There was a significant correlation $(p<0.05)$ between the cost and the carbohydrate availability. The energy and nutrients have not reached the nutritional requirement of the students. Thus, the adequacy level of the energy, protein, vitamin $\mathrm{C}$, and iron was categorized as severely deficit. The carbohydrate adequacy level classified as normal, while the fat adequacy level classified as excessive. The study suggested the management of the Boarding School to review the existing budget for meals in order to ensure the menu could meet the nutritional requirement of the santri. Beside, efforts need to be taken to ensure improved balanced and healthy meal available for the santri.

Keywords: availability of food, cost control, food service, nutritional adequacy level

\section{ABSTRAK}

Pengelolaan biaya makan dalam sebuah institusi penyelenggaraan makanan harus menjadi perhatian agar ketersediaan energi dan zat gizi optimal dapat terpenuhi. Tujuan umum penelitian ini untuk menganalisis biaya yang ditetapkan terhadap ketersediaan makanan dan tingkat kecukupan santri putri Pondok Pesantren Darul Arqam Garut. Penelitian dilakukan bulan April hingga Juni 2015 dengan menggunakan desain cross-sectional. Sampel diambil secara purposif dengan total 86 orang. Penyelenggaraan makanan di Pondok Pesantren Darul Arqam Garut dilakukan oleh industri jasa boga (catering) rumahan. Hasil penelitian menunjukkan bahwa pihak penyelenggaraan makanan mampu menggunakan 88,09 persen dari total dana yang diberikan oleh pondok pesantren. Hasil uji korelasi Pearson menunjukkan, tidak ada hubungan $(p>0,05)$ antara biaya dengan ketersediaan energi, protein, lemak, vitamin dan mineral. Terdapat hubungan yang signifikan $(p<0,05)$ antara biaya dengan ketersediaan karbohidrat. Kandungan energi dan zat gizi lainnya dalam makanan yang disediakan oleh pondok pesantren belum mencapai angka kebutuhan gizi santri. Tingkat kecukupan energi, protein, vitamin dan mineral tergolong kategori defisit berat. Tingkat kecukupan karbohidrat tergolong normal, sedangkan tingkat kecukupan lemak tergolong lebih. Disarankan kepada pihak manajemen melakukan peninjauan ulang terhadap pembiayaan untuk menjamin pemenuhan kebutuhan gizi santri, di samping upaya-upaya untuk perbaikan menu makanan yang seimbang dan sehat bagi santri.

Kata kunci: ketersediaan, pengelolaan biaya, penyelenggaraan makanan, tingkat kecukupan gizi 


\section{PENDAHULUAN}

$\mathrm{P}$ emenuhan kebutuhan pangan merupakan hak azasi setiap orang. Konsumsi makanan seseorang yang kurang dari kebutuhan gizinya akan mengalami gangguan kesehatan dan berisiko terkena penyakit yang berkaitan dengan gizi. Makanan harus mengandung energi dan zat gizi, seperti protein, lemak, karbohidrat, vitamin dan mineral, yang diperlukan tubuh untuk melaksanakan fungsinya, serta harus aman dikonsumsi. ${ }^{1}$

Salah satu faktor penting tercapainya sumberdaya manusia (SDM) yang berkualitas adalah kecukupan zat gizi dan pangan. ${ }^{2}$ Kecukupan zat gizi ini harus mulai diperhatikan sejak anak, remaja sampai dewasa. Remaja merupakan salah satu SDM yang perlu diperhatikan secara serius, terutama mengenai asupan gizinya. Kualitas masa depan Indonesia dipandang dari sisi pembangunan sangat dipengaruhi oleh keberadaan remaja sebagai penerus bangsa. Perkembangan remaja berlangsung mulai umur tigabelas sampai delapanbelas tahun. Kelompok umur remaja menunjukkan fase pertumbuhan yang pesat, yang disebut "adolescence growth spurt". Kebutuhan gizi remaja relatif besar, karena masih mengalami pertumbuhan. Selain itu, remaja umumnya melakukan aktivitas fisik lebih tinggi dibandingkan dengan usia lainnya, sehingga diperlukan zat gizi yang lebih banyak. ${ }^{3}$

Remaja putri rentan mengalami kurang gizi pada periode puncak tumbuh kembang. Hal ini bisa disebabkan kurangnya asupan zat gizi karena pola makan yang salah, serta pengaruh dari lingkungan pergaulan (berkeinginan untuk langsing). Laporan Riset Kesehatan Dasar (Riskesdas) menyebutkan, prevalensi anemia pada perempuan (>15 tahun) sebesar 20 persen. Remaja putri yang kurang gizi tidak dapat mencapai status gizi yang optimal (kurus, pendek, dan pertumbuhan tulang tidak proporsional), kurang zat besi dan zat gizi lain yang penting untuk tumbuh kembang. ${ }^{3}$

Data Riskesdas $(2010)^{4}$ menyebutkan bahwa 54,4 persen remaja di Indonesia mengonsumsi energi di bawah kebutuhan minimal (< 70\% Angka Kecukupan Gizi). Remaja merupakan penentu kualitas SDM yang diharapkan dapat meneruskan cita-cita pembangunan. Untuk itu aspek kesehatan dan gizi pada masa remaja perlu diperhatikan.
Masalah gizi pada remaja dapat terjadi pada setiap remaja, tidak terkecuali pada remaja yang menuntut ilmu di pondok pesantren. Santri merupakan siswa atau siswi yang sedang menuntut ilmu di pondok pesantren. Marudut menyatakan, berdasarkan hasil wawancara dengan Dinas Kesehatan, bahwa program kesehatan jarang menyentuh kelompok santri remaja putri. ${ }^{5}$ Oleh karena itu topik ini memperkaya penelitian tentang remaja yang tinggal di pondok pesantren putri. Umumnya, santri yang belajar di pondok pesantren berusia 7-19 tahun (anak usia sekolah dan remaja). ${ }^{6}$

Kementerian Agama menyatakan bahwa penyediaan makanan untuk santri ada yang disediakan pondok dan ada juga yang disediakan sendiri oleh santri dengan cara memasak secara tradisional. ${ }^{6}$ Adanya penyelenggaraan makanan di sebuah pondok pesantren memudahkan para santri dalam memenuhi kebutuhan gizi di tengah padatnya proses belajar mengajar yang sedang mereka tempuh. Abdulkareem et al. ${ }^{7}$ menyatakan bahwa kebiasaan makan santri sangat erat kaitannya dengan penyelenggaraan makanan yang ada di pondok pesantren karena setiap hari santri mengonsumsi makanan yang disediakan oleh pihak pesantren. Ketersediaan energi dan zat gizi yang disediakan penyelenggara makanan juga harus disesuaikan dengan kebutuhan gizi para santri yang ada.

Ketersediaan zat gizi ini terpenuhi jika didukung oleh anggaran biaya yang memadai, selain itu kreativitas pihak penyelenggara makanan dalam menyiasati anggaran juga sangat diperlukan. Peneliti tertarik untuk menganalisis biaya makan yang disediakan terhadap ketersediaan zat gizi serta tingkat kecukupan santri, khususnya putri di Pondok Pesantren Darul Arqam Garut. Penelitian ini bertujuan untuk menganalisis hubungan biaya makan yang ditetapkan terhadap ketersediaan makanan serta tingkat kecukupan santri putri Pondok Pesantren Darul Arqam, Garut.

\section{METODE PENELITIAN}

\section{Desain, Tempat, dan Waktu Penelitian}

Penelitan ini menggunakan desain crosssectional yang dilaksanakan di Pondok Pesantren Darul Arqam, Garut, Jawa Barat. 
Waktu pengambilan data penelitian dimulai dari bulan April hingga Juni 2015.

\section{Jumlah dan Cara Pemilihan Sampel}

Jumlah sampel yang digunakan dalam penelitian ini adalah 86 santri. Pemilihan sampel dilakukan dengan cara random sampling. Jumlah santri putri minimal yang dijadikan sampel dalam penelitian ini, dihitung menggunakan rumus Slovin, ${ }^{8}$ adalah 85 santri. Kriteria inklusi santri yang dijadikan unit analisis antara lain santri putri, tidak sedang menjalani diet, bersedia mengikuti alur penelitian sampai akhir, dan dalam keadaan sehat.

\section{Jenis dan Cara Pengumpulan Data}

Data yang dikumpulkan terdiri atas data penyelenggaraan makanan yang didapatkan dengan wawancara dan pengamatan langsung. Data konsumsi makanan santri didapatkan dengan metode estimated food record selama tujuh hari. Data karakteristik dan antropometri (usia, berat badan, dan tinggi badan) didapatkan dengan pengukuran langsung menggunakan timbangan berat badan digital dan microtoise. Data sekunder juga dikumpulkan dalam penelitian ini, yang terdiri atas data keadaan umum Pondok Pesantren Darul Arqam, data biaya makan untuk penyelenggaraan makanan, dan data rencana anggaran dan perencanaan menu dari pengelola penyelenggaraan makanan.

\section{Pengolahan dan Analisis Data}

Data biaya total yang diterima pondok pesantren dianalisis secara deskriptif, kemudian dibandingkan dengan biaya yang dikeluarkan untuk penyelenggaraan makanan. Biaya yang dikeluarkan untuk setiap menu dihitung menggunakan aplikasi minimalisasi biaya pangan. Data ketersediaan makanan dihitung menggunakan estimasi porsi yang diambil santri pada saat makan, kemudian dikonversi ke dalam satuan energi (kkal), protein (g), lemak (g), karbohidrat (g), zat besi (mg), dan vitamin C (mg) dengan merujuk pada Daftar Komposisi Bahan Makanan (DKBM) 2010 dan 'software' Nutrisurvey.

Data energi dan zat gizi diperoleh dengan menggunakan metode food record, meliputi jenis dan jumlah bahan pangan yang dikonsumsi dalam Ukuran Rumah Tangga (URT) atau dalam satuan gram (g). Data tersebut kemudian dikonversi menjadi satuan energi dan zat gizi lainnya.

Data karakteristik individu dan antropometri dianalisis secara deskriptif menggunakan Microsoft Excel. Kebutuhan gizi sampel dengan status gizi normal dihitung dengan AKG terkoreksi, dan sampel dengan status gizi lebih ditentukan dengan pendekatan Angka Kecukupan Gizi 2013. Tingkat kecukupan energi dan zat gizi lainnya sampel dinyatakan dalam persen, kemudian diklasifikasikan sesuai dengan kategori tingkat kecukupan. Uji korelasi Pearson digunakan untuk menganalisis hubungan antara biaya dengan tingkat kecukupan gizi, sedangkan uji korelasi Spearman digunakan untuk menguji hubungan antara biaya dengan ketersediaan gizi.

\section{HASIL}

\section{Penyelenggaraan Makanan Input penyelenggaraan makanan.}

Penyelenggara makanan menyediakan makan utama tiga kali dalam satu hari dengan waktu makan yang sudah terjadwal. Siklus menu yang dipakai menggunakan sistem siklus menu tujuh hari. Berdasarkan Palacio dan Theis ${ }^{8}$, tipe sistem penyelenggaraan makanan yang ada di pondok pesantren Darul Arqam adalah conventional system. Pembelian bahan pangan dilakukan secara mandiri dan langsung disiapkan untuk disajikan kepada santri (on-site food service). Jumlah tenaga kerja pengelola makanan adalah 19 orang. Dana yang disediakan pondok untuk menyediakan makanan santri per bulan adalah $\mathrm{Rp}$ 459.480.000. Dana tersebut merupakan dana untuk segala kebutuhan penyelenggaraan makanan, meliputi pembelian bahan pangan, upah karyawan dan biaya operasional lainnya.

\section{Proses penyelenggaraan makanan.}

Perencanaan menu dilakukan oleh pihak penyelenggara makanan pondok pesantren, kemudian dikonsultasikan dengan kepala bagian kerumahtanggaan dan dokter pondok pesantren. Perencanaan menu disesuaikan dengan dana dan variasi masakan, tetapi belum memperhatikan kebutuhan gizi dan kebiasaan makan santri. Penyelenggara makanan pondok pesantren Darul Arqam melakukan pengadaan bahan pangan dengan metode informal or open-market buying, yaitu membeli sendiri 
bahan pangan di pasar. 9 Pembelian bahan pangan dilakukan harian dan bulanan tergantung menu yang akan disediakan pada hari itu. Proses persiapan dan pengolahan dipimpin oleh kepala dapur dan dilaksanakan bersama-sama oleh para petugas pengolah dan penyaji tanpa mempergunakan standar resep.

Output penyelenggaraan makanan.

Kemenkes telah menetapkan porsi makanan seimbang yang dianjurkan dalam satu hari. ${ }^{10}$ Porsi makanan pokok yang baik adalah 3-4 porsi atau sekitar $300-400 \mathrm{~g}$, porsi protein hewani adalah 2-4 porsi (70-140 g/2-4 potong daging sapi sedang atau 80-160 g/2-4 potong daging ayam sedang), porsi protein nabati adalah 2-4 porsi (100-200 g/4-8 potong tempe sedang atau 200-400 g/4-8 potong tahu sedang), porsi buah adalah $150 \mathrm{~g}$ per hari, porsi sayuran adalah $250 \mathrm{~g}$. Tabel 1 menjelaskan jumlah setiap jenis makanan dalam gram yang disediakan di pondok pesantren.

Tabel 1

Jumlah Setiap Jenis Makanan (gram) yang Disediakan Pondok Pesantren pada Siklus Menu 7 Hari

\begin{tabular}{lccccc}
\hline \multirow{2}{*}{ Hari } & \multicolumn{5}{c}{ Jenis Makanan (gram) } \\
\cline { 2 - 5 } & $\begin{array}{c}\text { Makanan } \\
\text { Pokok }\end{array}$ & $\begin{array}{c}\text { Protein } \\
\text { Hewani }\end{array}$ & $\begin{array}{c}\text { Protein } \\
\text { Nabati }\end{array}$ & Buah-Buahan & Sayuran \\
\hline Sabtu & 300 & 80 & 65 & 0 & 35 \\
Minggu & 300 & 55 & 20 & 0 & 35 \\
Senin & 300 & 115 & 30 & 0 & 25 \\
Selasa & 300 & 70 & 20 & 0 & 50 \\
Rabu & 300 & 85 & 10 & 0 & 40 \\
Kamis & 300 & 120 & 65 & 0 & 0 \\
Jumat & 300 & 105 & 30 & 0 & 0 \\
\hline Rata-rata & 300 & 90 & 34 & 0 & 26 \\
\hline
\end{tabular}

Tabel 2

Rincian Pengeluaran Biaya Setiap Bulan

\begin{tabular}{|c|c|c|c|c|c|}
\hline $\begin{array}{c}\text { Dana yang } \\
\text { diberikan (Rp) }\end{array}$ & Jenis Pengeluaran & $\begin{array}{l}\text { Frekuensi/ } \\
\text { Bulan }\end{array}$ & $\begin{array}{l}\text { Harga Satuan } \\
\text { (Rp) }\end{array}$ & Total (Rp) & $\begin{array}{c}\text { Persentase } \\
\text { terhadap Dana } \\
\text { yang Diberikan } \\
(\%)\end{array}$ \\
\hline \multirow[t]{5}{*}{459480000} & $\begin{array}{l}\text { Food Cost } \\
\text { Biaya Bahan Pangan } \\
\text { Biaya Bumbu } \\
\text { Labor Cost } \\
\text { Operating Cost }\end{array}$ & $\begin{array}{l}4 \\
1\end{array}$ & $\begin{array}{l}79752300 \\
34581000 \\
28400000\end{array}$ & $\begin{array}{r}319009200 \\
34581000 \\
28400000\end{array}$ & $\begin{array}{r}76,95 \\
6,18\end{array}$ \\
\hline & $\begin{array}{l}\text { Biaya Operasional } \\
\text { - Listrik } \\
\text { - Air } \\
\text { - Pemeliharaan alat } \\
\text { - Sampah } \\
\text { - Gas }\end{array}$ & $\begin{array}{l}1 \\
- \\
-\end{array}$ & $\begin{array}{r}850000 \\
- \\
-\end{array}$ & $\begin{array}{r}850000 \\
- \\
-\end{array}$ & 0,60 \\
\hline & & $\begin{array}{c}1 \\
10 \\
\end{array}$ & $\begin{array}{l}400000 \\
150000\end{array}$ & $\begin{array}{r}400000 \\
1500000 \\
\end{array}$ & \\
\hline & Overhead Cost & & & 20000000 & 4,35 \\
\hline & Total Pengelua & ulan & & 404740200 & 88,09 \\
\hline
\end{tabular}


Tabel 3

Perkiraan Biaya Makan per Hari (Pagi, Siang, Malam) yang Dikeluarkan dari Setiap Menu

\begin{tabular}{ccccc}
\hline Menu Hari ke- & Pagi (Rp) & Siang (Rp) & Malam (Rp) & Total/Hari (Rp) \\
\hline 1 & 2.970 & 6.192 & 3.961 & 13.123 \\
2 & 3.019 & 3.179 & 4.691 & 10.889 \\
3 & 3.899 & 3.569 & 3.727 & 11.195 \\
4 & 2.970 & 5.929 & 4.316 & 13.215 \\
5 & 3.445 & 7.137 & 5.743 & 16.326 \\
6 & 4.783 & 4.988 & 3.668 & 13.438 \\
7 & 3.445 & 3.867 & 3.668 & 10.980 \\
\hline & $3.504 \pm 659$ & $4.980 \pm 1.499$ & $4.253 \pm 760$ & $12.738 \pm 1.942$ \\
\hline
\end{tabular}

Tabel 4

Tingkat Ketersediaan Energi dan Zat Gizi Lainnya pada Siklus Menu 7 Hari Pondok

\begin{tabular}{ccccccc}
\hline \multirow{2}{*}{ Hari ke- } & \multicolumn{5}{c}{ Tingkat Ketersediaan (\%) } \\
\cline { 2 - 7 } & Energi & Protein & Lemak & Karbohidrat & Zat besi & Vitamin C \\
\hline 1 & 67,7 & 55,0 & 103,8 & 62,4 & 44,6 & 0,8 \\
2 & 65,0 & 50,6 & 125,9 & 42,8 & 42,6 & 56,8 \\
3 & 56,6 & 46,5 & 71,1 & 63,4 & 22,9 & 24,6 \\
4 & 67,0 & 52,7 & 96,3 & 55,7 & 42,3 & 5,0 \\
5 & 53,9 & 48,6 & 53,1 & 58,0 & 36,6 & 14,1 \\
6 & 59,4 & 59,4 & 74,9 & 62,2 & 54,3 & 4,5 \\
7 & 55,7 & 43,1 & 73,0 & 51,2 & 19,6 & 2,4 \\
\hline Rata-rata & 60,8 & 50,9 & 85,4 & 56,5 & 37,6 & 15,5 \\
\hline
\end{tabular}

\section{Karakteristik Sampel}

Usia sampel sebagian besar $(69,8 \%)$ berada pada kelompok remaja awal (11-13 tahun). Rata-rata kebutuhan energi sampel adalah $2142 \mathrm{kkal}$, protein 68,36 g, lemak 71,62 $\mathrm{g}$, karbohidrat $294,41 \mathrm{~g}$, zat besi $25,13 \mathrm{mg}$, dan vitamin C $62,82 \mathrm{mg}$. Sebanyak 75.6 persen sampel dikategorikan status gizi normal, dan 24,4 persen sampel berstatus gizi lebih (overweight dan obesitas). Batubara ${ }^{11}$ menyatakan bahwa perkembangan badan remaja terutama perempuan lebih cepat pada komposisi lemak. Hal tersebut sesuai dengan permasalahan gizi yang sedang dihadapi setiap negara yaitu overweight dan obesitas. ${ }^{12}$

\section{Dana dan Perencanaan Anggaran}

Pihak pondok pesantren menetapkan biaya makan per hari per santri sebesar Rp 14.000. Total biaya yang terkumpul untuk mendanai penyelenggaraan makanan selama satu bulan adalah Rp 459.480.000. Tabel 2 menjelaskan mengenai rincian pengeluaran dana setiap bulan.

Perkiraan biaya bahan pangan yang dikeluarkan per hari untuk setiap menu disajikan dalam Tabel 3. Biaya tertinggi yang dikeluarkan penyelenggara makanan untuk menyediakan satu menu adalah pada menu makan siang di hari kelima. Biaya terendah yang dikeluarkan pihak penyelenggara adalah menu makan pagi hari pertama dan keempat.

\section{Ketersediaan Energi dan Zat Gizi}

Penilaian terhadap ketersediaan energi dan zat gizi lainnya dilakukan selama tujuh hari sesuai dengan siklus menu yang berlaku. Tingkat ketersediaan dihitung dengan cara membandingkan ketersediaan energi dan zat gizi lainnya dalam menu yang disediakan oleh pondok terhadap Angka Kecukupan Energi dan zat gizi sampel dalam sehari. Tabel 4 menjelaskan tingkat ketersediaan energi dan zat gizi pada menu pondok pesantren. Tingkat 
ketersediaan lemak pada hari ke-1 dan ke-2 melebihi 100 persen AKG. Energi dan zat gizi lainnya belum memenuhi AKG sampel. Secara umum persentase ketersediaan energi dan zat gizi lainnya yang ada di pondok pesantren belum memenuhi AKG. Rata-rata tingkat ketersediaan lemaklah yang paling tinggi diantara rata-rata tingkat ketersediaan zat gizi lainnya, yaitu 85,4 persen AKG. Rata-rata ketersediaan zat gizi yang paling rendah adalah vitamin $C$ yang hanya 15,5 persen AKG.

\section{Konsumsi Pangan}

Asupan energi dan zat gizi total sangat minim dan berbeda jauh dengan angka kecukupan gizi sampel. Hampir 50 persen lebih zat gizi terpenuhi melalui makanan yang disediakan pondok pesantren. Kecuali untuk vitamin $C$ yang sebagian besar terpenuhi dari luar pondok pesantren/makanan jajanan.

Makanan yang telah disediakan oleh penyelenggara makanan idealnya dimakan seluruhnya oleh santri karena itu merupakan makanan utama mereka. Kenyataannya masih ada santri yang memilih untuk makan dari luar pondok, salah satunya dari kantin atau warung di dalam pondok. Hal ini dimungkinkan rasa bosan santri dengan makanan yang disediakan pondok. Waktu antrean yang relatif lama juga bisa menjadi salah satu faktor santri kurang minat untuk makan makanan pondok. Ketersediaan zat gizi juga kurang optimal tersedia terutama vitamin dan mineral sehingga santri lebih memilih memenuhi zat gizi yang tidak ada tersebut dari luar makanan pondok.

\section{Tingkat Kecukupan Energi dan Zat Gizi}

Tingkat kecukupan energi dan protein sampel mayoritas berada pada kategori defisit berat $(66,3 \%)$. Hal ini sejalan dengan data Riset Kesehatan Dasar yang menyatakan bahwa persentase konsumsi energi untuk remaja di Indonesia masih kurang. ${ }^{12}$ Jumlah makanan yang tersedia di asrama, peraturan tentang makanan di asrama, sikap (daya terima) mereka terhadap makanan tertentu, dan kuantitas makanan yang disajikan juga mempengaruhi asupan energi. ${ }^{13}$ Uji korelasi pearson menunjukkan bahwa tidak ada hubungan yang signifikan $(p>0,05)$ antara ketersediaan energi dengan tingkat kecukupan energi. Hubungan yang signifikan $(p<0,05$; $r=0,823)$ ditunjukkan antara uji ketersediaan protein dengan tingkat kecukupan protein.

Tabel 5

Distribusi Rata-rata Konsumsi dan Kontribusi Asupan dari Dalam dan Luar Pondok Pesantren

\begin{tabular}{llccc}
\hline \multirow{2}{*}{ Variabel } & \multirow{2}{*}{ Zat Gizi } & \multicolumn{3}{c}{ Rata-rata } \\
\cline { 3 - 4 } & & Pondok & Luar Pondok & Total \\
\hline \multirow{4}{*}{ Konsumsi } & Energi (kkal) & 872 & 528 & 1399 \\
& Protein $(\mathrm{g})$ & 19,9 & 9,8 & 29.8 \\
& Lemak $(\mathrm{g})$ & 38,9 & 23,6 & 62.6 \\
& Karbohidrat $(\mathrm{g})$ & 114,6 & 82,1 & 196,7 \\
& Zat Besi $(\mathrm{mg})$ & 4,3 & 3,1 & 7,3 \\
& Vitamin C $(\mathrm{mg})$ & 3,3 & 8,1 & 11,4 \\
\hline \multirow{6}{*}{ Kontribusi } & Energi & 61,7 & 38,3 & 100,0 \\
Asupan (\%) & Letein & 67,0 & 33,0 & 100,0 \\
& Karbohidrat & 62,2 & 37,8 & 100,0 \\
& Zat Besi & 58,9 & 41,1 & 100,0 \\
& Vitamin C & 58,9 & 41,1 & 100,0 \\
& & 37,5 & 62,5 & 100,0 \\
\hline
\end{tabular}


Tabel 6

Distribusi Sampel Berdasarkan Tingkat Kecukupan Energi dan Protein

\begin{tabular}{lcccc}
\hline \multirow{2}{*}{ Kategori } & \multicolumn{2}{c}{ Energi } & \multicolumn{2}{c}{ Protein } \\
\cline { 2 - 5 } & $\mathrm{n}$ & $\%$ & $\mathrm{n}$ & $\%$ \\
\hline Defisit Berat $(<70 \%$ AKG) & 57 & 66,3 & 82 & 95,3 \\
Defisit Sedang (70-80\% AKG) & 11 & 12,8 & 2 & 2,3 \\
Defisit Ringan (80-90\% AKG) & 10 & 11,6 & 1 & 1,2 \\
Normal (90-120\% AKG) & 6 & 7,0 & 1 & 1,2 \\
Lebih $(>120 \%)$ & 2 & 2,3 & 0 & 0,0 \\
\hline \multicolumn{1}{c}{ Jumlah } & 86 & 100,0 & 86 & 100,0 \\
\hline
\end{tabular}

Tingkat kecukupan lemak sampel berada pada kategori lebih dengan 73,3 persen. Hal ini mengindikasikan bahwa asupan energi sampel sebagian besar disumbang oleh asupan lemak. Rata-rata kontribusi lemak terhadap energi melebihi nilai anjuran energi gizi makro (AMDR).${ }^{14}$ Sesuai dengan uji korelasi pearson yang menunjukkan bahwa terdapat hubungan yang signifikan $(p<0,05 ; \quad r=0,859)$ antara ketersediaan lemak dengan ketersediaan energi. Uji korelasi pearson menunjukan juga bahwa terdapat hubungan yang signifikan $(p<0,05$; $r=0,936)$ antara ketersediaan lemak dengan tingkat kecukupan lemak sampel.

Mayoritas tingkat kecukupan karbohidrat sampel berada ada kategori normal, yaitu sebanyak 55,8 persen. Uji korelasi pearson menunjukan bahwa tidak terdapat hubungan yang signifikan $(p>0,05)$ antara ketersediaan karbohidrat dengan tingkat kecukupan karbohidrat.

Jumlah persentase tingkat kecukupan zat besi dan vitamin $C$ sampel sama banyak, yaitu sebanyak 98,8 persen defisit. Penelitian Moreno et al. menyatakan bahwa mayoritas remaja di Eropa memiliki status kecukupan vitamin dan mineral yang kurang. ${ }^{15}$ Kecukupan zat besi yang kurang diduga karena tingkat kecukupan protein sampel yang mayoritas tergolong defisit. Andriana dan Sumarmi menyebutkan bahwa pada umumnya masyarakat yang cukup asupan proteinnya, maka asupan zat besi juga akan terpenuhi. ${ }^{16}$ Sesuai dengan hasil uji korelasi pearson yang menunjukkan terdapat hubungan yang signifikan $(p<0,05 ; r=0,833)$ antara tingkat kecukupan zat besi dengan tingkat kecukupan protein. Uji korelasi pearson juga menunjukan bahwa terdapat hubungan yang signifikan $(p<0,01 ; r=0,959)$ antara ketersediaan zat besi dengan tingkat kecukupan zat besi. Ketersediaan vitamin $C$ juga memiliki hubungan yang signifikan $(p<0,01 ; \quad r=0,964)$ dengan tingkat kecukupan vitamin C. Artinya, makin tinggi ketersediaan zat besi dan vitamin $\mathrm{C}$, maka semakin tinggi pula tingkat kecukupannya.

\section{Hubungan Antar-Variabel}

Hasil uji korelasi spearman menunjukkan bahwa tidak ada hubungan yang signifikan $(p>0,05)$ antara biaya makan yang dikeluarkan dengan ketersediaan energi, protein, lemak, zat besi, dan vitamin $\mathrm{C}$. Hubungan yang signifikan $(p<0,05 ; \quad r=0.494)$ ditunjukkan antara biaya makan dengan ketersediaan karbohidrat. Drewnowski dan Darmon menyatakan bahwa terdapat hubungan negatif antara biaya pangan dengan ketersediaan energi dan protein. ${ }^{17} \mathrm{Uji}$ korelasi pearson menunjukan tidak adanya hubungan yang signifikan $(p>0,05)$ antara biaya makan dengan tingkat kecukupan energi dan zat gizi lainnya sampel.

\section{BAHASAN}

Proses penyelenggaraan makanan di Pondok Pesantren Darul Arqam telah dilaksanakan cukup baik. Output penyelenggaraan makanan berupa masakan dinilai masih belum memenuhi standar porsi yang ditetapkan Kemenkes. ${ }^{9} \mathrm{Hal}$ ini disebabkan perencanaan menu yang dilakukan oleh penyelenggara makanan belum memperhatikan kebutuhan gizi santri. Jenis makanan yang memenuhi standar porsi berdasarkan Kemenkes hanya makanan pokok. ${ }^{9}$ Standar menu pondok pesantren yang telah dibuat 
belum mencantumkan standar porsi. Menu yang ada di pondok pesantren secara kualitatif cukup baik, namun secara kuantitatif masih kurang baik. Hal ini terbukti dengan tidak seimbangnya porsi antar jenis makanan, bahkan tidak tersedia buah-buahan dan porsi sayuran sangat kecil.

Kementerian Keuangan menyatakan bahwa standar biaya pengadaan makanan wilayah Jawa Barat yang ditetapkan untuk siswa/mahasiswa yang diasramakan di lingkup sekolah kedinasan adalah Rp 30.000 per orang per hari. ${ }^{18} \mathrm{Hal}$ ini adalah acuan standar yang disarankan oleh kementerian keuangan dalam pengadaan makanan wilayah Jawa Barat. Artinya bahwa dengan uang sejumlah tersebut, diharapkan mampu memenuhi kebutuhan makan untuk siswa atau mahasiswa.

Secara umum ketersediaan energi dan zat gizi yang ada di Pondok Pesantren Darul Arqam belum memenuhi angka kecukupan. Tingkat ketersediaan lemak lah yang paling tinggi diantara tingkat ketersediaan zat gizi lainnya, yaitu 85,4 persen AKG. Ketersediaan zat gizi paling sedikit adalah vitamin $C$ yang hanya 15,5 persen AKG.

Institute of Medicine (IOM) menyatakan bahwa pola makan seimbang yang dianjurkan untuk usia 4-18 tahun berdasarkan kontribusinya terhadap energi adalah 15 persen protein, 30 persen lemak, serta 55 persen karbohidrat. ${ }^{19}$ Kontribusi makan siang dan makan malam terhadap total kecukupan gizi sehari dianjurkan sekitar 2/5 AKG $(40 \%$ total kecukupan). Hal ini dapat diasumsikan bahwa kontribusi untuk makan pagi sekitar 1/5 AKG atau 20 persen dari total kecukupan sehari untuk individu. Rata-rata kontribusi protein terhadap total energi yang disediakan tidak mencapai 15 persen dari anjuran IOM.19 Kontribusi lemak melebihi anjuran yang telah ditetapkan, sedangkan rata-rata kontribusi karbohidrat kurang dari anjuran kecuali untuk makan siang yang menyediakan 59,4 persen dari total energi. Ketersediaan zat besi dan vitamin C pada setiap waktu makan masih kurang dari anjuran yang ditetapkan. Hasil perhitungan menyatakan bahwa ketersediaan makanan masih kurang beragam.

Persentase makan pagi yang dianjurkan adalah 20 persen, sedangkan makan siang dan malam sekitar 40 persen dari total asupan sehari. Persentase energi yang disediakan pada waktu pagi rata-rata hanya sekitar 17,3 persen dari total asupan sehari. Makan siang hanya menyumbang 21,8 persen, dan makan malam menyumbang 21,7 persen dari total asupan energi sehari.

Uji korelasi menyatakan tidak adanya hubungan antara biaya dengan tingkat kecukupan energi dan zat gizi sampel. Korelasi yang tidak signifikan pada penelitian ini diduga karena terdapat faktor lain yang mempengaruhi tingkat kecukupan gizi individu, diantaranya konsumsi pangan, preferensi terhadap makanan, daya terima, tingkat kesukaan, dan ketersediaan zat gizi. Jetter et al. menyatakan bahwa terdapat perbedaan pola konsumsi antara lingkungan pendapatan tinggi (highincome) dengan lingkungan pendapatan rendah (low-income). ${ }^{20}$ Lingkungan pendapatan tinggi cenderung mengonsumsi makanan sehat begitu pula sebaliknya. Hal ini dapat disamakan dengan kondisi penyelenggaraan makanan di pondok pesantren. Dana yang diberikan kepada pihak penyelenggara makanan merupakan income yang perlu dikelola dengan baik sehingga mampu menghasilkan output berupa makanan yang sesuai dengan prinsip gizi seimbang.

\section{SIMPULAN DAN SARAN}

\section{Simpulan}

Kegiatan prosedur penyelenggaraan makanan di Pondok Pesantren Darul Arqam Garut telah dilakukan dengan baik. Usia sampel mayoritas berada pada rentang usia remaja awal. Rata-rata kebutuhan energi sampel sekitar $2142 \mathrm{kkal}$, protein $68,36 \mathrm{~g}$, lemak 71,62 $\mathrm{g}$, karbohidrat $294,41 \mathrm{~g}$, zat besi $25,13 \mathrm{mg}$, dan vitamin C 62,82 mg. Status gizi sampel mayoritas berada pada kategori normal. Perkiraan biaya yang digunakan untuk penyelenggaraan makanan adalah 88,09 persen. Ketersediaan energi dan zat gizi lainnya yang ada di penyelenggaraan makanan Pondok Pesantren Darul Arqam belum memenuhi angka kecukupan gizi. Tingkat kecukupan energi, protein, vitamin, dan mineral sampel tergolong defisit berat. Tingkat kecukupan lemak tergolong lebih, dan tingkat kecukupan karbohidrat berada pada kategori normal. 


\section{Saran}

Pengelola pondok pesantren sebaiknya dapat lebih bijak dalam memformulasikan dana untuk penyelenggaraan makanan dengan cara meninjau ulang biaya dari pihak manajemen pondok pesantren atau dilakukan rapat dengan orang tua untuk menambah biaya makan. Pihak penyelenggara makanan pondok pesantren diharapkan mampu menyusun menu yang sesuai dengan kebutuhan gizi santri, sehingga dapat membantu meningkatkan status kesehatan jasmani santri. Ahli gizi profesional dianjurkan untuk dilibatkan dalam proses penyelenggaraan makanan di Pondok Pesantren Darul Arqam. Edukasi mengenai kandungan gizi bahan pangan perlu dilakukan kepada karyawan penyelenggara makanan. Ketersediaan protein dan zat besi masih kurang dari segi kualitas dan kuantitas, sehingga diharapkan penyediaan makanan sumber protein hewani dapat dioptimalkan. Ikan dapat dimasukkan ke dalam menu makanan seharihari di Pondok Pesantren Darul Arqam. Sosialisasi tentang pola makanan sehat kepada santri perlu dilakukan. Sosialisasi juga perlu dilakukan kepada pengelola kantin dan warungwarung di dalam pondok pesantren agar mereka dapat menyediakan makanan sehat bagi para santri.

\section{RUJUKAN}

1. Sati VP. Issues and options of food security and poverty: an empirical study of mizoram, the eastern extension of the Himalaya. J Food Secur. 2015:107-114.

2. Almatsier S. Prinsip Dasar IImu Gizi. Jakarta: Gramedia Pustaka Utama, 2009.

3. Serges M, Rogers GE. Energy profile and feeding status of young adult cameroonian university students. Front. Agric. Food. Technol. 2014; 2(4): 185-190.

4. Indonesia, Kementerian Kesehatan. Riset Kesehatan Dasar (Riskesdas) 2010. Jakarta: Balitbangkes Kemenkes RI, 2010.

5. Marudut. Efikasi bubuk tabur gizi terhadap status zat besi santri remaja putri di pondok pesantren. Disertasi. Bogor: Sekolah Pascasarjana IPB, 2012.

6. Indonesia, Kementerian Agama. Buku Statistik Pendidikan Agama dan Keagamaan Tahun Pelajaran 2008/2009. Jakarta: Kemenag RI, 2009.
7. Abdulkareem L, Garba D, Abubakar A. Assessment of food security in boarding schools using the HACCP system in Zaria Nigeria. Adv. Food. Sci. Technol. 2013; 1(3): 28-34.

8. Notoatmojo S. Metodologi Penelitian Kesehatan. Jakarta: Rineka Cipta, 2005.

9. Palacio-JP TM. Introduction to Foodservice, $11^{\text {th }}$ ed. New Jersey: Pearson Education, 2009.

10. Indonesia, Kementerian Kesehatan. Pedoman Gizi Seimbang 2014. Jakarta: Kemenkes RI, 2014.

11. Batubara JRL. Adolescent development (perkembangan remaja). Sari Pediatri. 2010; 12(1): 21-9.

12. Gillespie S, Haddad L, Allen L, Babu S, Horton. Attacking the double burden of malnutrition in Asia and the Pacific. ADB Nutrition and Development Series No. 4. 2001 Sep. xiv, 179 p.

13. Anyika AC, Uwaegbute AO, Olojede JU, Nwamarah. Nutrient intakes of adolescent girls in secondary schools and universities in Abia State of Nigeria. Pakistan J Nutr. 2009; 8(10): 1596-1602.

14. Hardinsyah, Hadi R, Victor N. Kecukupan energi, protein, lemak, dan karbohidrat. Dalam: Soekatri MYE, Muslimatun S, Purwanto, Ariani M, Hardinsyah, Egayanti $Y$, et al (editor). Widyakarya Nasional Pangan dan Gizi X: Presentasi dan Poster. Jakarta: LIPI Press, 2014. p. 897-925.

15. Moreno LA, M Gonza'lez-Gross, M Kersting, D Molna' $r$, S de Henauw, L Beghin et al. Assessing, understanding and modifying nutritional status, eating habits and physical activity in European adolescents: The HELENA (Healthy Lifestyle in Europe by Nutrition in Adolescence) Study. Public Health Nutr. 2007;11(3): 288-99.

DOI: $10.1017 / S 1368980007000535$.

16. Andriana D, Sumarmi S. Hubungan konsumsi protein hewani dan zat besi dengan kadar hemoglobin pada balita usia 13-36 bulan. IJPH. 2006; 3(1): 19-23.

17. Drewnowski A, Darmon N. Symposium: Modifying the food environment: energy density food costs and portion size (food choiches and diet costs: an economic analysis). J Nutr. 2005; 135: 900-904. 
18. Indonesia, Kementerian Keuangan. Peraturan Menteri Keuangan Republik Indonesia Nomor 53 tahun 2014 tentang Standar Biaya Masukan Tahun Anggaran 2015. Jakarta: Kemenkeu RI, 2014.

19. Institute of Medicine. Dietary Reference Intake for Energy, Carbohydrate, Fiber, Fat, Fatty Acids, Cholesterol, Protein, and Amino Acids. A Report of the Panel on Macronutrients, Subcommittees on Upper
Reference Levels of Nutrients and Interpretation and Uses of Dietary Reference Intakes, and the Standing Committee on the Scientific Evaluation of Dietary Reference Intakes. Washington, DC: National Academies Press, 2005.

20. Jetter KM, Diana L, Cassady. The availability and cost of healthier food alternatives. Am J Prev Med. 2006; 30(1): 38-44. 